\title{
Helping Your Child with Homework ${ }^{1}$
}

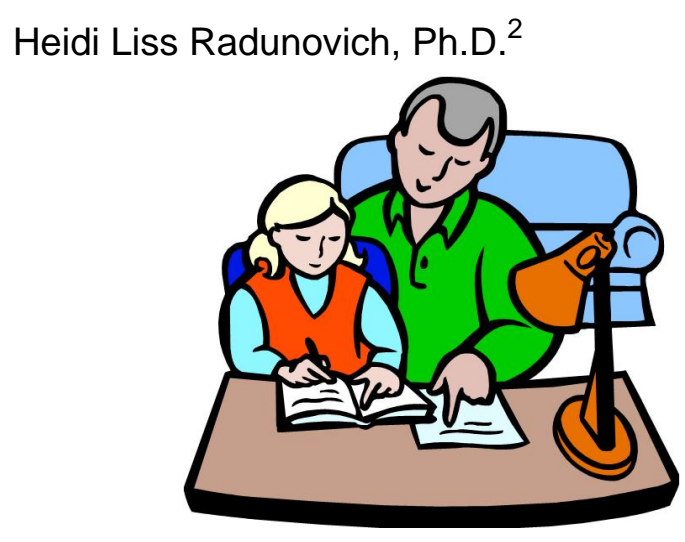

Educators disagree about whether homework helps students learn, what type of homework should be given, and how much is enough. The fact is that nearly all students from elementary school through high school will receive homework on a regular basis. Homework can provide important opportunities for children to:

- practice what they have learned in school

- get more in-depth information

- apply skills more broadly

- obtain important learning and organizational skills

- learn how to work independently with self-discipline
Homework also helps parents get a sense of what their children are doing in school, find out how well they are doing, and improve their relationships with their children.

However, getting children to do their homework can be hard for parents. First, it can be difficult to know whether or not children have homework. Many children forget to write down assignments, and others forget that they have homework, or do not tell the truth about having homework. Second, finding time in children's increasingly busy lives to complete the work can be a challenge. Third, many children don't enjoy the work, so they may put it off, rush through it, or get into a battle of wills with parents over it. Finally, some children have learning or behavioral issues that make it hard for them to do their homework, which causes frustration for both children and parents.

The amount and type of homework that is given varies widely, even within the same school and grade. Generally, as children get older, they receive more homework, and the homework becomes more difficult. The US Department of Education suggests ten to twenty minutes of homework a day for kindergarteners through second-graders, and thirty to sixty minutes per day for third- through sixth-graders.

1. This document is FCS2255, one of a series of the Family Youth and Community Sciences Department, Florida Cooperative Extension Service, Institute of Food and Agricultural Sciences, University of Florida. Original publication date October 1, 2006. Visit the EDIS Web Site at http://edis.ifas.ufl.edu.

2. Heidi Liss Radunovich, assistant professor, Department of Family, Youth and Community Sciences, Institute of Food and Agricultural Sciences, University of Florida, Gainesville, FL, 32611.

The Institute of Food and Agricultural Sciences (IFAS) is an Equal Opportunity Institution authorized to provide research, educational information and other services only to individuals and institutions that function with non-discrimination with respect to race, creed, color, religion, age, disability, sex, sexual orientation, marital status, national origin, political opinions or affiliations. U.S. Department of Agriculture, Cooperative Extension Service, University of Florida, IFAS, Florida A. \& M. University Cooperative Extension Program, and Boards of County Commissioners Cooperating. Larry Arrington, Dean 
Amounts can increase for grades seven through twelve. However, teachers and schools have different policies regarding homework. If you think your child has too much or too little homework, talk to your child's teacher about your concerns.

The kind of help children need from parents may also change as children get older. For example, younger children may need to be watched closely while completing homework. They may need frequent help from parents in order to understand the assignment. Older children will probably need less help in completing their homework, but you may need to check their homework for mistakes and make sure that it gets finished.

Research has shown that boys have a harder time than girls with the motivation and organizational skills they need to successfully complete homework. They may need more help from you. Children who are insecure about their academic abilities may also need you to encourage them. Check over their homework with them and help them to understand their mistakes, understand the material, and correctly complete the work.

There is no one right way to set up rules for homework. Every child and family has different needs, styles, and resources. However, finding a system that works well for your child is important. Setting up good study and homework habits early on will make it easier to do homework successfully as children get older. Here are some suggestions that may help children succeed with homework:

\section{Set a regular family quiet time for working. It} helps to have a family quiet time set aside in the afternoon or evening for study, reading, and working on homework. Even if children do not have homework that day, they should participate in this quiet time. Children without homework can use the time to read, write letters, review school lessons, study, or do research. Children are less likely to lie about not having homework if they know they will still need to participate in quiet time.

2. Find a good location. It is helpful to set aside a comfortable place in the home where the child can do homework, such as a desk or a kitchen table with a chair. Make sure there is good lighting. Younger children will need more help, so pick a location where you can watch them easily.

3. Get rid of distractions. Turn off the TV and make video games off-limits during quiet time. Although some children seem to enjoy working while listening to music, there is some research that suggests that music can be distracting. If you do let children listen to music while working, make sure that the music is quiet and does not bother other children who are working. If your child has a hard time concentrating for long periods of time, set a kitchen timer and reward the child with a break when the timer goes off.

4. Have resources available. Make sure that your child has pens, pencils, notebook paper, or any other supplies he/she may need. If children need information from the library or a computer, help them to get access to what they need. If you are not sure how your child should do the homework, that is okay! You just need to know where to send your child to get the information. You might need to use a homework hotline, Internet sources, other children in the class, or a teacher's before- or after-school help.

\section{Show interest and enthusiasm about your} child's homework. Ask about the assignment, and show interest in the topic. Talk to your child about how to do the assignment and what it means. Children will be more interested and enthusiastic about their homework if you show interest and enthusiasm. Posting work that received good grades on the refrigerator or keeping a folder with special work in it shows children that you are interested and care about their work. When a child shows you something he or she has done well, share his or her pride and make positive comments about it.

6. Set a good example. Children watch what we do. If we model good study skills, read, and organize our time well, our children will learn from our examples.

7. Be available. Make sure that you or another responsible adult is available to monitor homework time. Be a coach for your children, helping them if they get stuck, checking their 
work when they are finished, or even helping them test themselves on new skills. You can also help them break big jobs down into smaller ones, stay organized, and manage their time.

\section{Give praise and encouragement. Homework} can be tiring and frustrating. Make sure to praise children for their efforts, even if they are struggling. Give children the message that they are capable of doing the homework and that you believe in them. Encourage them to take breaks after they finish smaller tasks so that they don't get too tired or restless.

\section{Ask teachers what to expect regarding} homework. Teachers have different rules on homework, so check in with your child's teacher at the beginning of the school year to find out what to expect. If the amount of homework seems to be too much or too little for your child, or if your child is always struggling with homework, make sure to talk to your child's teacher about your concerns.

\section{Don't do your child's homework! Although}

this may be tempting at times, it is important for children to do the work themselves. If you do the work for them, they will not be learning. Also, this gives children the message that you think they can't do the work, and that completing homework is not important.

If your efforts to help your child with homework are not successful, or if you struggle a lot with learning or behavioral issues, it might be a good idea to get help from professionals. Your child's teacher or guidance counselor may have some ideas for helping with homework. If you need more help, he or she can refer you to professionals in the community, such as tutors or mental health professionals.

\section{References}

Gurung, R. (2005). How do students really study (and does it matter)? Teaching of Psychology, 32, 239-291.

Margolis, H. (2005). Resolving struggling readers' homework difficulties: Working with elementary school learners and parents. Preventing School Failure, 50, 5-12.
Margolis, H. \& McCabe, P.P. (2004). Resolving struggling readers' homework difficulties: A social cognitive perspective. Reading Psychology, 25, 225-260.

National Education Association. Help your student get the most out of homework. Retrieved August 17, 2006, from http://www.nea.org/parents/homework.html

Pomerantz, E.M., Ng, F.F., \& Wang, Q. (2006). Mothers' mastery-oriented involvement in children's homework: Implications for the well-being of children with negative perceptions of competence. Journal of Educational Psychology, 98, 99-111.

Pomerantz, E.M., Wang, Q., \& Ng, F.F. (2005). Mothers' affect in the homework context: The importance of staying positive. Developmental Psychology, 41, 414-427.

Simplicio, J.S.C. (2005). Homework in the $21^{\text {st }}$ century: The antiquated and ineffectual implementation of a time honored educational strategy. Education, 126, 138-142.

Trautwein, U., Lüdtke, O., Schnyder, I., \& Niggli, A. (2006). Predicting homework effort: Support for a domain-specific, multilevel homework model. Journal of Educational Psychology, 98, 438-456.

U.S. Department of Education. Helping your child with homework. Retrieved August 17, 2006, from

http://www.ed.gov/parents/academic/help/homework/ index.html

$\mathrm{Xu}$, J. (2006). Gender and homework management reported by high school students. Educational Psychology, 26, 73-91.

Zimmerman, B.J., \& Kitsantas, A. (2005). Homework practices and academic achievement: The mediating role of self-efficacy and perceived responsibility beliefs. Contemporary Educational Psychology, 30, 397-417. 